DOI: $10.4274 /$ tpa.695

\title{
A case of primary polydipsia presenting with severe malnutrition
}

\author{
Gülseren Evirgen Şahin1, Pelin Zorlu22, Nilgün Demirli Çaylan2, Şit Uçar2, Esma Altınel Açoğlu22, Gürses Şahin3 \\ ${ }^{1}$ Celal Bayar University Medical Faculty, Division of Pediatric Gastroenterology, Manisa, Turkey \\ 2Dr. Sami Ulus Women's and Children's Health Research and Training Hospital, Clinic of General Pediatrics, Ankara, Turkey \\ ${ }^{3}$ Dr. Sami Ulus Women's and Children's Health Research and Training Hospital, Division of Pediatric Oncology, Ankara, Turkey
}

\section{Summary}

Primary polydipsia is a clinical status with excessive fluid consumption without any physiological need. A seventeen-month-old male infant with severe malnutrition and developmental retardation was found to have polyuria and polydipsia in the follow-up. The urine density was found to be 1001, Na was found to be $124 \mathrm{mEq} / \mathrm{L}$ and the serum and urine osmolarity was found to be low. The patient was diagnosed with primary polydipsia and was treated by gradual water restriction. This case is presented to emphasize that primary polydipsia changes nutritional habits which may lead to malnutrition and developmental retardation. (Turk Arch Ped 2013; 48: 251-254)

Key words: Childhood, malnutrition, primary polydipsia

\section{Introduction}

Diabetes insipidus is a syndrome characterized with poliuria and polydipsia which occurs as a result of disruption of tubular water absorption because of central or nephrogenic causes (1). While central diabetes insipidus occurs because of inadequate amount of antidiuretic hormon $(A D H)$ reaching the renal medulla, nephrogenic diabetes insipidus occurs because of inadequate renal response to $A D H$ and its equivalents without any disruption in production and release of $\operatorname{ADH}(2,3)$. Primary polydipsia is a defect characterized with excessive fluid consumption because of various causes independent of ADH without physiological requirement which is observed substantially rarely in the childhood and which should be considered in the differential diagnosis of diabetes insipidus (4).

In this article, a patients who was diagnosed with primary polydipsia while investigating the etiology of severe malnutrition and developmental retardation with the aim to emphasize the fact that primary polydipsia may lead to growth and developmental retardation and malnutrition by altering feeding habits.

\section{Case}

A 17-month-old male patient presented to our clinic with complaints including inability to gain weight and walk. From the history it was learned that he was born by cesarean section with a birth weight of $3100 \mathrm{~g}$ from the third pregnancy of a 23-year-old healthy mother as the second living child. He was exclusively breastfed in the first three months. The family started to give plenty amount of water to the patients with the recommendation of the relatives during acute gastroenteritis which occured at the age of three months, lasted for five days and improved without need for oral or intravenous fluid treatment. The mother continued to give her child plenty of water after acute gastroenteritis was recovered thinking that it would be beneficial for the child's health. The child had no other acute gastroenteritis attack afterwards. Meanwhile, the infant's reluctance against breastmilk started. Since weight gain slowed down during the follow-up in the primary care setting, formula was started at the age of four months and supplementay food was started at the age of 6 months with the recommendation of the healthcare personnel. During 
this period, the infant was always reluctant to feeding, but received water easily. After the age of 9 months propensity to drink water increased furhter and he started to wake up for 3-4 times at night. The neuromotor development of the patient was normal until the age of 6 months. Afterwards, the family realized that he was retarded compared to his peers. He could hold his head high at the age of one month and started to sit with support at the age of 9 months. At the present time, he can not sit without support and he can not walk. In his familial history, the parents were thirddegree relatives, he had a 2.5-year old healthy sister and no significant disease was present in the family.

On physical examination, his general status was well, he appeared weak and poor, he had scarce and unlively hair. His body weight was $7000 \mathrm{~g}(<3 \% \mathrm{p})$, his height was $78 \mathrm{~cm}(10-25 \% \mathrm{p})$ and head circumference was $46 \mathrm{~cm}(10-$ $25 \%$ p). His subcutaneous adipose tissue was reduced. The classification of malnutrition was severe malnutrition according to Gomez, marasmus according to Wellcome and acute+chronic according to Waterlow. On neurological examination, the muscle tonus was decreased, deep tendon reflexes were hypoactive, he could sit with support and could not sit or walk without support. Other physical examination findings were found to be natural.

The laboratory tests were as follows: Hemoglobin: $8.6 \mathrm{gr} / \mathrm{dL}, \mathrm{MCV}: 64 \mathrm{fL}, \mathrm{RDW}$ : 15.8 , WBC: 16 900/mm3, platelets: $449000 / \mathrm{mm}^{3}$, CRP: $<1 \mathrm{mg} / \mathrm{L}$, blood glucose: 74 $\mathrm{mg} / \mathrm{dL}$, BUN: $3 \mathrm{mg} / \mathrm{dL}$, creatinine: $0.25 \mathrm{mg} / \mathrm{dL}$, sodium: 124 $\mathrm{mEq} / \mathrm{L}(\downarrow)$, potassium: $3.5 \mathrm{mEq} / \mathrm{L}$, chloride: $95.5 \mathrm{mEq} / \mathrm{L}$, calcium: $8.8 \mathrm{mg} / \mathrm{dL}$, phosphorus: $3.3 \mathrm{mg} / \mathrm{dL}$, alkaline phosphatase: $63 \mathrm{IU} / \mathrm{L}$, AST: $40 \mathrm{U} / \mathrm{L}$, ALT: $18 \mathrm{U} / \mathrm{L}$, urinary $\mathrm{pH}: 7.5$, urinary density: 1001 , urinary protein: negative, urinary sodium: $<5 \mathrm{mEq} / \mathrm{L}$, urinary osmolarity: $39 \mathrm{mOsm} /$ $\mathrm{kg}$, serum osmolarity: $259 \mathrm{mOsm} / \mathrm{kg}$. Arterial blood gases and throid function tests were found to be normal.

When daily fluid received and excreted was followed up, it was observed that he ingested $3500 \mathrm{cc}$ and excreted 3150 cc. Primary polidipsia was considered primarily because of hyponatremia, a urinary density of 100 , a simultaneous serum osmolarity of $259 \mathrm{mOsm} / \mathrm{kg}$ and a urinary sodium of $<5 \mathrm{mEq} / \mathrm{L}$. Water restriction test was not done, since the patient had hyponatremia and severe malnutrition and his status was poor. It was decided to treat the patient by decreasing the amount of water gradually in two weeks. Primarily, hyponatremia was improved with intravenous fluid treatment and did not recur in the followup. His diet was adjusted with age-appropriate food. In addition, supplemantations of multivitamin, folic acid and trace elements $(\mathrm{Mg}, \mathrm{Cu})$ was given. Iron was also added to the treatment two weeks later because of iron deficiency anemia. At the end of the second week of gradual fluid restriction, the urinary density increased to 1020 , urinary osmolarity increased to $820 \mathrm{mOsm} / \mathrm{kg}$ and serum osmolarity increased to $290 \mathrm{mOsm} / \mathrm{kg}$. Meanwhile, the patient's appetite improved and he achieved a body weight of $8200 \mathrm{~g}$ in a period of two weeks by a weight gain of 1200 g. At the time of discharge, he could sit without support and stand on his feet by holding on (the findings of the patient at the baseline and after fluid restriction are summarized in Table 1). The patient was discharged after his diet was adjusted to continue his physical therapy program at home.

\section{Discussion}

Primary polydipsia is a specific disorder of thirst function and may be observed rarely in all age groups (5). Physical activity, environmental temperature, food intake and habits affect daily fluid intake. Unnecessary and excessive fluid intake independent of fluid loss or hypertonicity of body fluids is defined as primary polydipsia. Primary polydipsia may develop in relation with hypothalamic damage or dysfunction, compulsion, habits, psychological problems. It may also be iatrogenic due to deficient and erroneous information (1,3).

Polydipsia is generally tolerated well until hyponatremia and related sequelae occur. Severe neurological symptoms are not observed unless the serum sodium level decreases below $125 \mathrm{mEq} / \mathrm{L}$. When fluid intake exceeds urinary excretion capacity, hyponatremia accompanies the picture and findings of water intoxication including vomiting, lethargia, agitation, skeletal muscle dysfunction, weakness, convulsion, coma and even death occur $(5,6,7,8,9)$. In addition, findings including enlargement in the bladder and intestines, hydronephrosis, renal failure, malnutrition and eating disorders may appear because of excessive drinking of water $(10,11,12)$. In our patient, the findings at presentation included severe malnutrition which was a result of defective feeding due to excessive water intake and growth and developmental retardation. Complaints at presentation did not include drinking excessive water and frequent urination, because the family considered this as

\begin{tabular}{|l|c|c|c|c|c|}
\hline \multicolumn{1}{|c|}{ Table 1. Summary of the findings at presentation and at the end of the second week of treatment } \\
\hline & Body weight $\mathbf{( g )}$ & $\begin{array}{c}\text { Urinary } \\
\text { osmolarity } \\
\text { (mOsm/kg) }\end{array}$ & $\begin{array}{c}\text { Serum osmolarity } \\
\text { (mOsm/kg) }\end{array}$ & $\begin{array}{c}\text { Urinary } \\
\text { density }\end{array}$ & $\begin{array}{c}\text { Serum Na } \\
\text { (mEq/lt) }\end{array}$ \\
\hline Baseline & 7000 & 39 & 259 & 1001 & 124 \\
\hline Second week & 8200 & 820 & 290 & 1020 & 135 \\
\hline
\end{tabular}


a normal state. It was thought that iatrogenic polydipsia which started with the recommendation of the relatives during acute gastroenteritis and continued as the family resumed this behavior caused to this picture in our patient. Daily intake of $3500 \mathrm{cc}$ fluid during the clinical follow-up and presence of accompanying polyuria and supportive laboratory findings and hyponatremis suggested the diagnosis of primary polydipsia.

Primary polydipsia is observed substantially rarely in the childhood. The majority of the cases with primary polydipsia in the literature are adults who have severe psychiatric disorders $(5,7)$. Grela and Oblacinska (14) reported three iatrogenic cases which occured because of presentation of excessive water by the parents and were diagnosed during the infancy. Grunberg et al. (15) reported one patient who started to consume excessive water at the age of 20 months and was diagnosed at the age of 3 years. Horev et al. (16) reported five patients with primary polydipsia whose ages ranged between 6 months and 20 months. In a 18-month-old infant, an association of primary polydipsia and subclinical primary hypothroidism was defined (17). Some cases of primary polydipsia presenting with severe hyponatremia and water intoxication arising from erroneous desmopressin treatment due to inadequate differential diagnosis of polyuria and polydipsia have been reported in the literature $(11,13)$.

Malnutrition and eating disorders may arise as complications of primary polydipsia. A small number of cases with association of eating disorders, anorexia nervosa and primary polydipsia have been defined in adults and adolescents in the literature $(18,19,20)$. However, it is observed that eating disorder is not a result of primary polydipsia in these cases, when the association of primary polydipsia and eating disorder is examined. In our patient, primary polydipsia started before and malnutrition and developmental retardation occured as a result of primary polydipsia. Although alternation of feeding habits and loss of appetite due to primary polydipsia is an expected finding, there is no patient presenting with malnutrition and developmental retardation among the cases of primary polydipsia in infancy and early childhood reported in the literature, as far as we know.

In the differential diagnosis of polyuria and polydipsi, diabetes mellitus, diabetes insipidus, mineral imbalances including hypokalemia and hypercalcemia, renal pathologies and primary polydipsia should be considered. Water restriction test is required to differentiate diabetes insipidus from primary polydipsia (21). Increase of urinary osmolarity above $600 \mathrm{mOsm} / \mathrm{kg}$ during fluid restriction test is enough for a diagnosis of primary polydipsia. A diagnosis of diabetes insipidus is made, when the urinary osmolarity does not increase above $600 \mathrm{mOsm} / \mathrm{kg}$ and is maintained at the level of $200-300 \mathrm{mOsm} / \mathrm{kg}$ most of the time, although the serum osmolarity is above $300 \mathrm{mOsm} / \mathrm{kg}$. At the end of the test, desmopressin test is applied in patients whose urinary density does not increase and the differentiation of central and nephrogenic diabetes insipidus is made (1). Disorders in plasma sodium level is one of the reasons for not applying water restriction test. Since both hyponatremia and severe malnutrition were present in our patient and his general status was poor, it was considered that his balance would easily be disrupted and water restriction test could not be performed.

The aim in treatment of primary polydipsia is altering the behavior of drinking water and fluid restriction and psychiatric support are enough in treatment in most cases (13). Hyponatremia was improved primarily in our patient and gradual fluid restriction and improvement of feeding for malnutrition were applied and vitamin and mineral supplements were given afterwards. In the second week of treatment, it was observed that the urinary density increased to 1020 , the urinary osmolarity increased to $820 \mathrm{mOsm} / \mathrm{kg}$, the serum molarity increased to $290 \mathrm{mOsm} / \mathrm{kg}$, the patient's appetite increased and he started to gain weight. Thus, the diagnosis of primary polydipsi was supported with the response given to gradual fluid restriction performed during a two-week period, though diagnostic fluid restriction test was not performed in the patient. In addition, the family was informed about the harms of excessive water and continuance of treatment was provided. At the follow-up visit performed two weeks after discharge, it was observed that the clinical and laboratory findings were normal and weight gain continued.

Primary polydipsia which develops in relation with various causes in the childhood may affect the somatic and motor development negatively by altering feeding habits. Care should be taken while recommending to give plenty of water to children during acute gastroenteritis and pyretic diseases and the amount and duration of water which should be given should be absolutely explained.

\section{References}

1. Tarım Ö. Diabetes insipidus, Uygunsuz ADH sendromu, serebral tuz kaybı. Güncel Çocuk Sağığı 2008; 1: 280-288.

2. McKinley MJ, Cairns MJ, Denton DA, Egan G, Mathai ML, Uschakov A, Wade JD, Weisinger RS, Oldfield BJ. Physiological and pathophysiological influences on thirst. Physiol Behav 2004; 81: 795-803.

3. Robertson GL. Clinical disorders of the posterior pituitary. In: Pescowitz OH, Eugster EA, (eds). Pediatric endocrinology. Philadelphia: Lippincott Williams\&Wilkins, 2004: 90-107.

4. Bode HH, Crawford JD, Danon M. Disorders of antidiuretic hormone homeostasis. In: Lifshitz F, (ed). Pediatric endocrinology. New York: Marcel Dekker Inc, 1996: 731-751.

5. Cronin RE. Psychogenic polydipsia with hyponatremia: Report of eleven cases. Am J Kidney Dis 1987: 9: 410-416.

6. Mcnally RJ, Calamari JE, Hansen PM, Kaliher C. Behavioral treatment of psychogenic polydipsia. J Behav Ther Exp Psychiat 1988: 19: 57-61. 
7. Dundas B, Haris M, Narasimhan M. Psychogenic polydipsia review: etiology, differential and treatment. Curr Psychiatry Rep 2007; 9: 236-241

8. Singh $\mathrm{S}$, Padi $\mathrm{MH}$, Bullard $\mathrm{H}$, Freeman $\mathrm{H}$. Water intoxication in psychiatric patients. Br J Psychiatry 1985; 146: 127-131.

9. Mercier- Guidez E, Loas G. Polydipsia: review of the literatüre. Encephale 1998; 24: 223-229.

10. Bremner AJ, Regan A. Intoxicated by water polydipsia and water intoxication in a mental handicaped hospital. $\mathrm{Br} \mathrm{J}$ Psychiatry 1991; 158: 244-250.

11. Ferrer J, Halperin I, Conget JI, Cabre J, Esmatjes E, Vilardell E. Acute water intoxication after intranasal desmopressin in a patient with primary polydipsia. J Endocrinol Invest 1990; 13: 663-666.

12. Adelman RD, Shapiro SR, Woerner S. Psychogenic polydipsia with hydronephrosis in an infant. Pediatrics 1980; 65: 344-346.

13. Ergin H, Semiz S, Dağdeviren E. Psikojenik polidipsi: bir vaka takdimi. Çocuk sağlığı ve Hastalıkları Dergisi 2006; 49: 319-321.
14. Grela K, Oblacinska A. Psychogenic polydipsia in infants due to the wrong parental behavior. Pediatr Pol 1995; 70: 511-514.

15. Grunberg J, Gazzara G, Lopez P, Esquivel N. Psychogenic polydipsia in a child. Bol Med Hosp Infant Mex 1981; 38: 807-815.

16. Horev Z, Cohen $\mathrm{AH}$. Compulsive water drinking in infants and young children. Clin Pediatr 1994; 33: 209-213.

17. Şıklar Z, Tanyer G, Dallar Y, Demir M, Arıkan i. Süt çocukluğu döneminde bir primer polidipsi olgusu: Olgu sunumu. T Klin $\mathrm{J}$ Pediatr 1999; 8: 81-83.

18. Myers KM, Smith MS. Psychogenic polydipsia in a patient with anorexia nervosa. J Adolesc Health Care 1985; 6: 404-406.

19. Barjau JM, Chinchilla A. Primary polydipsia and eating disorders: three case reports. Actac Esp Psiquitar 2000; 28: 137-139.

20. Bahia A, Chu ES, Mehler PS. Polydipsia and hyponatremia in a woman with anorexia nervosa. Int J Eat Disord 2011; 44: 186-188.

21. Tarım Ö. Çocuklarda su dengesi bozuklukları. Türkiye Klinikleri J Pediatr Sci 2006; 2: 108-114. 